\title{
Positioning Muslims in Ethnic Relations, Ethnic Conflict and Peace Process in Sri Lanka
}

\author{
Mohammad Agus Yusoff ${ }^{1}$, Nordin Hussin ${ }^{1} \&$ Athambawa Sarjoon ${ }^{1}$ \\ ${ }^{1}$ School of History, Politics and Strategic Studies, University Kebangsaan Malaysia, Malaysia \\ Correspondence: Mohammed Agus Yusoff, School of History, Politics and Strategic Studies, University \\ Kabangsaan Malaysia, UKM Bangi 43600, Selangor, Malaysia. E-mail: agus_ukm@yahoo.com
}

Received: February 20, 2014 Accepted: March 7, 2014 Online Published: April 29, 2014

doi:10.5539/ass.v10n10p199 URL: http://dx.doi.org/10.5539/ass.v10n10p199

\begin{abstract}
Sri Lankan Muslims, the second largest minority ethnic group with 9.4 per cent (2012) of the total population has been victimized in the cause of ethnic politics, ethno-nationalism, and ethnic conflict in Sri Lanka. Like other ethnic groups in Sri Lanka, the Muslims also have a historical origin that follows a set of distinctive ethno-centric cultural and religious practices. They have contributed much to the communal harmony, socio-economic and political development of the country throughout the history of Sri Lanka. However, the ethnic distinctiveness of Sri Lankan Muslims has always been questioned and the community has been violently targeted in the cause of time. The ethnic politics and ethno-nationalism of both major ethnic groups, the Sinhalese and the Tamils have impacted a lot on the Muslims of Sri Lanka. Furthermore, most of the initiatives adopted to resolve the ethnic conflict have also failed to address the grievances and to accommodate the interests and demands of the Muslims. The devastating effects of the conflict on Muslim community and the continuous neglect of their interests in the discourses of peace process pushed them to politically mobilize for advocacy politics. On this backdrop, this paper pays attention on the historical survival of Muslim community, their position in ethnic politics and peace process in Sri Lanka. The main objective of this paper is to record the historical incidents related with the Muslims in Sri Lanka without pointing fingers at any party in these processes. The analysis of this paper is descriptive and interpretive in nature and only the secondary data is used for the analysis.
\end{abstract}

Keywords: Sri Lankan Muslims, ethnic relations, ethnic conflict, nationalistic politics, peace process

\section{Introduction}

Sri Lanka is one of the small nations in the world, covering an area of 65,610 square kilometers with pluralistic community and traditional heritages. It has been known by the natural gift of its beauty of marine and coastal belt, inland scenarios and exclusive resources, cultural and traditional heritages. These features have attracted many foreign travellers and merchants to visit and later to invade Sri Lanka. In fact, all major ethnic groups in the contemporary Sri Lanka are the descendants of other countries, i.e. the Sinhalese and Tamils are the descendants of India, while the majority of the Muslims are descendants of the Arab countries and Southern India. There were historical records of mutual goodwill and communal harmony among ethnic groups in Sri Lanka. However, in the later part, especially with the footprint of colonial powers, started with Portuguese in 1505 , not only the native ethnic groups were undermined by the colonial power but also the traditional amity among these communities was severely affected. The colonial rulers planted roots for divisions and differences and caused a lot of ethnic and societal differences and conflicts, which later prompted for ethno-nationalism, ethnic conflict and civil war in independent Sri Lanka. One of the ethnic groups severely affected by colonialism, ethno-nationalism and ethnic conflict in Sri Lanka is the Muslim community, who has a historical origin and being an integral part of Sri Lanka nation, tried to preserve the communal harmony and territorial integrity of the island. However, throughout the history, their grievances have been sidetracked. As Jezeema Ismail emphasizes, perhaps because it was such a peaceful relationship, it has passed unnoticed by the historians (Ismail, 2013). With this backdrop, this paper, is specially focused on the sidetracked history of the Muslims of Sri Lanka in the course of colonial rule, ethnic-nationalism, ethnic conflict and peace process in Sri Lanka. The rest of the article is divided into four major parts with the conclusion. The first part records the historical origin of the Muslims of Sri Lanka and their relations with the other ethnic groups with emphasis on the challenges they faced in the 
hands of the colonial rulers. The second part evaluates the impacts of ethno-nationalism, ethnic conflict and civil war on Muslims; the third part identifies the role of Sri Lanka Muslims congress; the first ever successful Muslim political party formed with Islamic fundamentals advocating the rights of Muslims; the fourth part of the article examines the position of Muslims in the process of peace building. Throughout the paper, an argument is developed, that even though the Muslims of Sri Lanka as a peace loving and patriotic community, contributed much to the ethnic harmony and territorial integrity of Sri Lanka, they remained sidelined by the ethno-nationalist politics of both major ethnic groups, the Sinhalese and the Tamils in the political process of Sri Lanka. Furthermore, their voices and demands have been excluded from the discourse of ethnic relations, ethnic conflict and peace process in Sri Lanka.

Even though the other ethnic groups, the Sinhalese and the Tamils have also been severely affected by ethnic conflict and civil war, this paper mainly focuses on the impact of exclusivity of the Muslim community-always identified as 'other party' not directly involved in the conflict and ever supported violent means to achieve their political aspirations, but always forgotten and sidetracked by the 'major parties'. Even though there has been conflict among religions in Sri Lanka, only the impact of ethnic conflict-conflict among ethnic groups is taken for analysis in this paper. Likewise, the Muslims' position in the context of ethnic conflict and peace process is examined based on their role in conflict situations and major peace talks and resolution packages.

\section{Muslims of Sri Lanka: Origin, Identity and the Relationship with Other Communities}

According to the census of 2012, the Muslim community in Sri Lanka constitutes 9.4 per cent of the total population. Among them, Sri Lankan Moor forms the majority, (99\%) and the Malays forms $0.8 \%$ and a small portion of Indian Muslims completes the remaining $0.2 \%$. With the Muslims scattered around the Island, one third of them are predominantly living in the Eastern province, while the rest are living in the other parts of the island. There is a heavy concentration of Muslim population in the three districts of Amparai (43.6\%), Batticaloa (25.5\%) and Trincomalee (40.4\%) which together comprise the Eastern province (Department of Census and Statistics, 2013). Majority of the Sri Lanka Muslims speak Tamil as their mother tongue, while majority of the Muslims living outside the North-Eastern provinces are capable of speaking Sinhala, the mother tongue of majority Sinhalese. Most of them are the descendants of Arab and South Indian traders and the rest have their origin from Malays and Javanese who were brought to the island during the Dutch colonial era in the seventeenth and eighteenth centuries and are now concentrated mostly in the Slave Island area of Colombo and in Hambantoda (McGilvray \& Raheem, 2007, p. 6). According to 2012 census, there are about 40,000 Malays in Sri Lanka. There is a historical root underpinned by language, culture and traditions of Muslims of Sri Lanka, dated back to 2000 years. Therefore, it is important to look at the history of the relationship of Arabs, South Indian and European traders and merchants in order to understand the historical origin of the Muslims of Sri Lanka and their relationship with other communities.

The historical evidences report that the relationship between Arab traders and Sri Lanka is more than 2500 years old and the relationship between Islam and Sri Lanka is nearly 1400 years old. However, there is no single document that records the historical origin of Sri Lankan Muslims as recorded for the Sinhalese and the Tamils (Note 1). The history of Sri Lankan Muslims could be traced from the works of foreign travelers who visited Sri Lanka. Even though they are not sufficient to collect the early history of Muslims in Sri Lanka, however, they help us to decide that the Muslims had relationships with Sri Lanka long before the birth of Christ. The Muslims who arrived in the island during the medieval period were a cosmopolitan crowd. Among them, there were Arabs, Persians, Egyptian, Abyssinians and Indians; and there were sailors and traders, religious messengers, travelers and physicians. As Ali (2001, p. 1) emphasized, none of them came to conquer territory or proselytize pagans, but rather were attracted to the shores of Sri Lanka by the abundance of value of its spices, pearls, ivory and gems. The sacred footprints of Adam's Peal also made an added attraction. Historical evidences further explain that the Arabs and Persians were in trade with Indians during $4^{\text {th }}$ and $5^{\text {th }}$ century and they established trading in the southern coast of India and visited Sri Lanka too (Note 2). It equally identified that the early settlements of Muslims in Sri Lanka could be found in eight (08) main towns closed to the main harbors in those days. Archaeological evidences, such as tomb stones, indicate that there were Muslim settlements in $10^{\text {th }}$ century in Anuradhapura, Trincomalee and Colombo. Most of these Muslims were the settlers of Arab traders who had integrated with the internal community through inter-marriages and cultural practices and identified as the first wave of Muslims that came to Sri Lanka.

The second wave of Muslims came to Sri Lanka from South India between $12^{\text {th }}$ to $15^{\text {th }}$ centuries. They were the descendants of earlier Arab traders who had settled in South Indian ports and married local women (Ali, 2004, p. 373). As a result, Tamil and Malayalam came to be written in Arabic scripts, and known as Arabic Tamil. Since it was compulsory for Muslim children to read the Koran-the holy book of Islam, they had to know Arabic Tamil. 
This partly explains why the Muslims who have lived for centuries in wholly Sinhala speaking areas retained Arabic Tamil as their mother tongue.

As Ameer Ali mentioned, until the advent of the Portuguese in the $16^{\text {th }}$ century, the entire Muslim elements of Sri Lanka's population did not consider a common ethnic name. Perhaps in the context of medieval Sri Lanka, there was no need for any such ethnic designation. In the absence of any significant conflict of interest between the host communities, i.e., Sinhalese and Tamils, and the guest community, the Muslims, a socio-economic atmosphere of mutual respect and laissez-faire prevailed, which in turn contributed to political harmony and societal peace (Ali, 2004, p. 373). Lorna Dewaraja pointed out that from the ancient period, right up to the Kandyan period; there was racial harmony/amity between the Sinhalese and the Muslims. The reason was that the Muslim traders were economically and politically assets to the Sri Lankan Kings. The Kings therefore provided protection and permission for the Muslim traders to settle in Sri Lanka (Dewaraja, 1994, p. 16). She further emphasized that the Islamic identity maintained by the Muslims not only allowed, but even encouraged them to strengthen their internal organization while integrating with the Kandyan society. Right through from the Anuradhapura period to Kandyan times, there was a Muslim lobby operating in Sri Lankan court which advised the Kings on overseas trade policy and also kept the Kings informed of developments abroad. The Muslim traders with their navigational skills and overseas contacts became the secret channel of communication between the court and the outside world. The Sri Lankan Kings encouraged the Muslims to maintain their links with the Islamic world as this was mutually beneficial (Dewaraja, 1994, p. 17).

It is worth noting that when Portuguese first appeared on the shores of Sri Lanka, the Muslims warned the King, sangha, nobles and the people, of the potential threat to the country's sovereignty and fought alongside with Sinhalese against the Portuguese. The Muslims later used their influence with the South Indian powers to get military assistance for Sinhalese rulers. Therefore, when the Dutch, the second colonial power in Sri Lanka persecuted the Muslims in their coastal settlements, the Muslims ran to the Kandyan Kingdom for protection. King Senerat (1604-1635) and Rajasingha-II (1635-1687) settled these Muslims in the Eastern coast, which was under their Kingdom. It was recorded that the King Senerat settled a large number of Muslims with Tamils in Dighavapi area of Batticaloa to revive the paddy cultivation (Godrington, 1970, p. 113). In fact, this has made the Muslims to constitute the majority in the present day Amparai district. Additionally, this settlement was viewed as to protect the Eastern flank of this Kingdom from the Portuguese fortification (McGilvray, 1998, p. 436). In this manner, Muslims were integrated into Kandyan society primarily by giving them duties related to the King's administration.

It was the Portuguese who bestowed upon the Muslims in Sri Lanka a single ethnic identity. To the mercantilist and missionary Portuguese however, the Arabs, the Persians and the Malays were all enemies not only in terms of commerce and trade but also in terms of religion. They grouped all of them together and called every Muslims as 'Moor' (Ali, 2004, p. 373). Between the Portuguese appellation of the Muslim community in the $16^{\text {th }}$ century and the last quarter of $19^{\text {th }}$ century, the name 'Moor' gained prominence at least in the official records. Until the 1880 s, the name 'Moor' appears to have had no ethnic significance at all as far as the Muslims of Sri Lanka were concerned. However, Muslims started to think and search for their distinct ethnic identity when Ponnambalam Ramanathan (later sir), the Tamil member of Legislative Council, made an insidious speech delivered in the Council on the debate of 'Muhammadan Marriage Registration Ordinance' in 1880s. In his speech, he attempted to stress the point that the Moors of Ceylon actually Tamils by origin (Ali, 2004, p. 374; Ali, 2001, p. 1). It is worth emphasize here that when colonial government was preparing to appoint a separate Muslim representative to the Legislative Council, if Ramanathan's theory was left unchallenged, the government would have been pressurized by the Tamils to disallow separate representation for Muslims. However, the Muslim community was quick to counter Ramanathan's theory. I.L.M. Abdul Azeez and M.C Siddi Lebbe spearheaded the anti-Ramanathan campaign, stressing the search for the historical origins and separate identity of Sri Lankan Muslims, which later brought success when the British governor appointed M.C Abdul Rahman as the first Muslim member to the Legislative Council in 1889. It must be emphasized here that the immediate response of the Muslim community to record the origin and the distinctive ethnic features of the Sri Lankan Muslims saved the community from unwanted questions and claims over the Muslims in Sri Lanka.

After the Ramanathan theory on the ethnic origin of Sri Lankan Muslims, Muslims woke up to assert their own identity and gained separate political representation. However, ethno-nationalism and ethnic conflicts hardened these pre-existing communal identities, and there were deep political divide between Sinhalese-Muslims, and Tamils-Muslims. Muslims of Sri Lanka now clearly have a separate ethnic identity, based fundamentally on their Islamic beliefs and culture which teaches tolerance, peace and harmony (International Crisis Group, 2007, p. 2; Balasingham, 2004, p. 3). Sri Lankan government also treat the muslin community as descendants of Arabs and 
distinct ethnic group from others, especially of Tamils. It is interesting to note that even though the Muslims of Sri Lanka speak Tamil and Sinhala and live side by side with other ethnic groups, sharing many things with them, however, it is their religion, Islam and the cultural practices based on Islamic fundamentals that make them a distinctive ethnic group in Sri Lanka. Muslims never identify themselves with the language they speak, for example, as 'Tamil Muslims' or 'Islamic Tamils', which is the identity for Muslims in Tamil Nadu, India.

The point to emphasize here is that the historical review of the origin and the settlement of Sri Lankan Muslims and their relationship with other (majority) ethnic groups in Sri Lanka clearly shows that the Muslims were the descendent of Arab traders and their settlement was purely on trade and business, and they had very good relationships with the host community in Sri Lanka. Therefore, at any point in time, they never act against the native community, but rather were with local rulers. However, at the later part of the colonial rule, especially during the nationalist agitations from the later part of twentieth century, Muslims were questioned on their origin, distinctive ethnic features and their patriotism. Later, in the course of post-independent governance, all these questions reacted in targeting Muslim's trade, business, religion, cultural practices, rights, and privileges through ethno-centric politics and policies.

\section{Ethno-Centric Politics, Ethnic Conflict and Muslims in Sri Lanka}

Even though the Muslims of Sri Lanka have maintained peace and social harmony with the host communities, they were not been treated as an equal ethnic group and always been questioned by the major ethnic groups of their ethnic origin, trade and commercial affairs. One of the first and the cynical incident that targeted both the origin and the economy of the Muslim community were the anti-Muslin riots of 1915. The rapid economic development of Muslims posed criticisms among Sinhala nationalists and earned the wrath of the Sinhalese masses which later led to the racist violence against the Muslims in the beginning of $20^{\text {th }}$ century. There were a number of anti-Muslims writings and propagandas too. To cite an example, the veteran Buddhist scholar and one of the founders of Buddhist nationalism in Sri Lanka, Anagarike Dharmapala in his anti-Muslim propaganda, traduced Sri Lanka's Muslims as follows:

'alien people ... [who] by shylockian methods became prosperous like the Jews. ... the alien South Indian Muhammedan comes to Ceylon, see the neglected illiterate villager, without any experience in trade, without any knowledge of any kind of technical industry and isolated from the whole of Asia on the account of his language, religion and race, and the result is Muhammedan thrives and the son of the soil goes to the wall' (DeVotta, 2004, p. 32).

No doubt that the Sinhalese who perpetrated the 1915 anti-Muslim riots evoked the same themes to justify their violence, since the above statement was published just some days before the riots. In these famous racial riots, Muslims were attacked, robbed, and killed by Sinhalese thugs (Ali, 2004, p. 374). The outbreak of violence in Kandy, which spread to Colombo and the North Western, Southern, Sabragamuwa, and Central Provinces, was targeted at the Muslims (Zackariya \& Sanmugarathnam, 1998, pp. 7-46). The fundamental cause of the 1915 riots was the economic exploits of the Muslim community and later took on religious grab. The event of 1915 has recorded a black mark to the ethno-nationalist history of Sri Lanka. Further to that, the incident was recorded as the first in the nature of majority-minority ethnic rivalry in Sri Lanka. However, among all these anti-Muslim sentiments and incidents, Muslims stood united and continued their socio-economic and political interactions with the majority ethnic groups, especially with Sinhalese. Muslims also aligned themselves with the independent movement and advocated for sovereignty, territorial and societal integrity of Sri Lanka. There was a generation of Muslim political leaders who became famous in national politics through the major Sinhalese parties, the United National Party (hereafter, UNP) and the Sri Lanka Freedom Party (hereafter, SLFP). Sir, Razik Fareed, T. B.Jaya (Malay origin), and M.C.M. Kaleel, Mackan Makar were popular among them.

However, in the cause of post-independence communal politics, the Muslim community, together with the Tamils was targeted and severely affected in many ways through the laws, acts, policies and projects adopted by the successive governments formed by the two major Sinhalese parties, the UNP and the SLFP. The review of some of the major acts, policies and projects clearly advocates this argument. It was the Ceylon Citizenship Act of 1948, and the Indian-Pakistani Residents Act of 1949, and The Ceylon Parliamentary Election (Amendment) Act of 1949, passed by the first independent government that had the ulterior motives to disenfranchise the larger Indian population in Sri Lanka (Gamage \& Watson, 1999, p. 52). Nearly a million of the working population including Indian and Pakistani Muslims were disenfranchised, which robbed them of their basic human rights and reduced them to an appealing condition of statelessness.

The successful attempt of making Indian-Pakistani descendant population disfranchised gave boost to the government to work towards weakening the positions of minorities. The successive government achieved this 
target through a number of projects. One of the major projects among them was the irrigation-based development projects which were initiated immediately after independence and followed by all the post-independent governments. The critical issue in these development initiatives however, was the settlement of Sinhala farmers on the lands in the Eastern province. These were Gal Oya, Kantalai and Allai during 1948-1978 period and Morawewa and Mahaweli in the post 1978 period. The main objection was the demographic and political consequences of the state-sponsored transfer of population (Gunethilaka, 2001, p. 32).

The emphasis here is that, the first massive development project in this regard, was implemented in Amparai district in the Eastern province under the Gal Oya irrigation scheme. The areas of the present Amparai district were under British Batticaloa district with the majority population of Muslims and Tamils. Amparai district was formed in 1961. Hundreds of thousands of archers of irrigation lands belonging to Tamils and Muslims were seized by the government and given to the newly colonized Sinhalese. These projects were carried out in violation of the land development laws. The result was progressive reduction of the percentage of Muslims and Tamils and the progressive increase of Sinhalese population in the newly formed Amparai district (Note 3). The project further marginalized the Muslims and Tamils as beneficiaries. An activist of Muslims rights, M.I.M. Mohideen criticized the land climes made by the Sinhalese in the Muslims areas as the same way the Jews have been perusing in Palestine to dispossess the Arabs of their homes (Mohideen, 2002, p. 7). According to the reports of district secretariat and census (2012), more than $78 \%$ of the district lands have been allocated to the $38.7 \%$ Sinhalese and about $22 \%$ of the land given/shared to the local administrative units where the Muslims and Tamils live. It is noteworthy that majority of the district population, $43.6 \%$ Muslims were allocated only $15.50 \%$ of total land and $17.5 \%$ Tamils allocated only $7.5 \%$ of total land in the district (Department of Census and Statistics, 2013).

The second major project which undermined the rights of minorities was the 'official language policy', projected and implemented by the post-independent Sri Lankan governments. It was popularly called 'Sinhala only Act' contributed much more to the abuse of minorities' collective rights, including Tamil speaking Muslims and paved ways for the violent ethnic conflict in Sri Lanka. Even though Mr. J.R Jeyawardena, the then Finance Minister had proposed that Sinhala be made the official language in 1944, however, the language rights issues became a question at the forefront of politics in the 1950s. The two major political parties, the UNP and the SLFP became advocates for 'Sinhala only' language policy from 1953. As Jeyawardena mansions (1990, pp. 121-122), between 1953 and 1956, the 'Sinhala Only' cry swept the country and it was used in favor of Sinhala being proclaimed the only official language, and to the exclusion of Tamil. During the 1956 election, inspired by $2500^{\text {th }}$ anniversary of the birth of the Great Buddha, the official language demand became narrow to 'Sinhala only'. Bandaranaike too promised to make 'Sinhala Only' a reality 'within 24 hours, if elected to power' (Ponnambalam, 1983, p. 98). After Bandaranaike came to power, the first legislation of his government was to realize the promise. The introduction of Sinhala as the only official language made Tamil language an inferior position. This later resulted in denying equal employment opportunities to Tamil speakers.

After a number of efforts, the Tamil was officially accepted as a state language, just like the Sinhala. The $13^{\text {th }}$ and the $16^{\text {th }}$ constitutional amendments declared Tamil as official administrative language of the North-Eastern provinces. However, the Tamil speaking community has been facing a number of challenges in fulfilling their daily administrative affairs in these provinces due to the non-implementation of the language laws and provisions by the administrative officials. The successive central governments and bureaucrats have shown little or no interests in implementing these provisions and admitting Tamil equally. It is evident that the successive central governments appointed Sinhala bureaucrats as heads of district and provincial administration, which allowed them to dominate administrative affairs. An especial reference on this regard is that the district administration of Amparai and Trincomalee in the Eastern province, which are not only predominant Tamil speaking districts but also Muslim majority districts have been dominated by the Sinhala administrators. From the inception of Amparai district in 1961, never ever a Tamil speaking officer was appointed to the position of district secretary - the head of district administration. All these initiatives have not only violated the fundamental rights of minorities ensured in the constitution, but also made it difficult to access the services of district secretariats. It can be argued that the Muslims' demand for an administrative district in the coastal belt of the Amparai district emerged partly because of the systematic violation of language rights and the neglect of the constitutional provisions and administrative orders.

All the systemic and purposive initiatives of the central government not only violated the rights of minorities, but also prompted them to mobilize and advocate for rights based claims and later for ethnic confrontation with major ethnic groups. The failure to accommodate the interests of ethnic minorities within the democratic political system, gave rise to violent armed struggle between the government forces and the liberation fighters of 
Tamils. The civil war started in the middle of 1980s and ended in 2009 impacted severely not only on ethnic groups but also on the entire sectors in Sri Lanka. One of the ethnic groups severely affected by the ethnic conflict and civil war, but mostly forgotten in the discourse of ethnic conflict and peace process is the Muslims of north-eastern Sri Lanka.

In the case of the North-Eastern Sri Lanka, Muslims had lived together with the majority Tamils and Sinhalese peacefully. There were no any significant conflicts or violent incidents between these communities in the history till 1980s. Especially in the Northern Province, the very small percent of Muslims (less than 5 per cent) lived together peacefully and cordially with majority Tamils sharing cultural and economic aspirations. A particular phenomenon in the Eastern province is that a Muslim village is interspersed with Tamil village and vice versa. This fragmented settlement pattern stressed the importance of inter-dependency and paved ways for peaceful co-existence in the province. The Muslims and the Tamils bonded economically, socio-culturally, and most importantly, politically. There were historical records that the prominent Muslim political leaders of the eastern province, such as Kate Muthaliyar. M. S. Kariyappar, and M. M. Mustaffa were been elected from the Tamil political party-Federal Party.

However, with the failure of political agitations of Tamils for equal rights and the emergence of their military nationalism, especially after the 1983 ethnic violence in the country, the ethnic relations of the North-Eastern Muslims with other ethnic communities also became severely affected and the innocent Muslims civilians, who supported or went against the Tamils nationalism, were violently targeted. This violent started in April 1985 with the firing of a Tamil separatist armed group in the vicinity of the Town Mosque of Akkaraippttu, a predominant Muslim town in the Amparai district (Fazil, 2005, p. 172). With this unfortunate incident, the Tamil-Muslim ethnic violence swiftly spread to other predominantly Muslim villages of Eastern province; namely Kalmunai, Kattankudy, Eravur, Oddamavady, Valaichenai, Mutur and Kinniya. Hundreds of Muslims were killed by the armed Tamil groups and many billions of rupees worth of properties belongs to both Tamils and Muslims were burnt and destroyed (Mohideen, 2002, p. 10).

There were a number of incidents which severely impacted on the North-Eastern Muslims. The murder of Mr. Habeeb Mohamed, the Assistant Government Agent (AGA) of Mutur on $3^{\text {rd }}$ September 1987; Tamils attacked and burned Muslim owned shops, rice mills and houses in the predominant Muslim towns of Kalmunain on the $10^{\text {th }}$ September 1987; displacement of the Muslims of Mutur due to the Tamil armed groups attacks in October 1987; the killing of Muslim Member of Parliament (MP) and Deputy Minister, Mr. A.L. Abdul Majeed, who was actively involved in the relief operation for the Mutur refugees on $13^{\text {th }}$ November 1987; the killing of Muslims and burning of their properties at Oddamavadi, a predominant Muslim village in Batticaloa district on $2^{\text {nd }}$ December 1987 due to the shells of Indian Peace-Keeping Forces; Tamil armed groups attacked and killed nearly 60 Muslims and burned their properties at Kattankudy, another predominant Muslim village in Batticaloa district on $30^{\text {th }}$ December 1987 were identified as some of the most important incidents (Mohideen, 2002, pp. 10-11). The worst incident of this nature perpetrated on the North-Eastern Muslims were held in 1990, namely August 1990 Massacres in Muslim villages of Kattankudy and Eravur in the Eastern province, and the forceful evacuation of the entire Muslims of the Northern province (which was labeled as 'ethnic cleansing' in the history of Muslim politics). Both made clear the ethnic divisions between the Tamils and the Muslims in these provinces and paved ways to form the Muslim nationalism movement.

In Kattankudy incident, it was reported, on $3^{\text {rd }}$ August, 1990, that more than 100 Muslim men and boys were killed while they were praying at Meera Jumma mosque and Hussainmiya mosque, by the LTTE gunmen. The August massacre in Kattankudy was followed by several weeks of attacks on the Muslim community, marked in many cases by extreme brutality (International Crisis Group [ICG], 2007, p. 7). Following this massacre, the LTTE staged another massacre on innocent Muslims in Eravur and killed 120 Muslims. When this massacre was reported, a Tamil human rights group described the incident as follows:

"LTTE cadre arrived in Eravur about 10.30 p.m on $11^{\text {th }}$ August 1990 and went about massacring Muslims until the early hours of the morning. They went through the Muslim areas of Surattayankuda, Michnagar, Meerakerni, Saddam Hussain Village and Pannakuda, killing 120 persons. Among the worst reported incidents was the cutting of a pregnant lady's stomach. The baby is said to have been pulled out and stabbed..." (Quoted by ICG, 2007, p. 7) (Note 4).

These events posed a huge stock to the Muslim community. Many Muslims fled outlying villages and areas of predominantly Tamil population to the more secure Muslim towns and villages along the eastern coast. Others abandoned paddy lands they owned in rural Tamil areas, fearing for their safety if they went out to cultivate rice fields. Many of these lands have remained inaccessible for Muslim owners ever since, and their loss was a 
significant source of tension between the two communities.

The August 1990 Eastern massacres had some reflections in the ethnic relations between Tamils and Muslims not only in the Eastern province but also in the Northern Province too. In the Northern Province there was no hostility of violent clashes between the major ethnic groups. However, when clashes between the Tamils and the Muslims increased in the Eastern province, Muslims started to mobilize under the Muslim separate political party, the Sri Lanka Muslim Congress (hereafter, SLMC). The LTTE took this political mobilization in a negative perspective. The result ended with the ethnic cleansing of the entire Muslims of the Northern Province with a three day deadline in October 1990. In Jaffna, the Muslims were given only two hours to leave and permitted to take only 150 rupees with them (Hasbullah, 2001, p. 45). Most of the displaced Muslims are still living in other parts of the island with the assistance of government and non-government organizations. The LTTE did not make an apology for the forceful ejection of the northern Muslims and allowed them to re-settle in their homeland until they were inactive. It was only at the end of the civil war in 2009, that the government made efforts to re-settle those Muslims on their own lands. However, there are still a number of issues prevailing on this.

The latest incident that targeted the Muslims of the Eastern province in the cause of ethnic conflict is the Mutur displacement of August 2006. There was heavy fighting between the government forces and the LTTE around Mutur in the early August, 2006 due to the LTTE control of the water distribution at the Mavil Aaru Sluice gate, which was the major water transaction sluice in the Trincomalee district. When government undertook a military offensive to capture the location on humanitarian ground, the LTTE cadres took control of Muttur, a Muslim village on the southern side of Trincomalee Bay (International Crisis Group, 2007, p. 16). Almost all the residents in and around Muttur fled due to the intense fighting that occurred between the government forces and the LTTE. More than 50,000 Muslims from Muttur and its surrounding villages fled to the neighboring safe villages such as Kanthalai and Kiniya respectively. Tamil residents fled to LTTE controlled areas. Muslims had apparently been assured of safe passage by the LTTE but near the hamlet of Panchanoor they were stopped by the LTTE cadres, who separated some 200 men from the women and children, apparently on suspicion that they were members of a 'Jihadi' group. Some were tied up, presumably pending execution. At this point, at least according to one report an artillery barrage landed nearby, killing several people, but allowing most of the captured Muslims to escape. According to some other reports, more than 100 men disappeared after this incident, but there had been no conclusive investigation (ICG, 2007, p. 16). These displaced Muslims languished for more than two months in inadequate shelters in various camps. They returned to their homes two months later. Many of their houses and public buildings were damaged or destroyed.

The point to emphasize here is that, even though the Muslim community of Sri Lanka have never resorted to violence and armed mobilization against the rulers or the majority ethnic groups in Sri Lanka, but rather contributed much to the ethnic, political and territorial integrity of the nation, they were simply the target of the ethno-centric politics and ethnic conflict in Sri Lanka. It is therefore noteworthy to say that timely emergence of a Muslim district political party; the Sri Lanka Muslim Congress (SLMC) protected the Muslim community from resorting to ethnic violence or violent mobilization. In fact, the advocacy politics of the SLMC was a timely relief to the vulnerable Muslims, especially those in the north-eastern part of Sri Lanka.

\section{Formation of Sri Lanka Muslim Congress (SLMC) and Its Advocacy Politics for Muslims}

An analysis of the Muslim political history shows that the politics of Sri Lankan Muslims had been in the hands of the two major Sinhalese parties, the UNP and the SLFP. Muslim politicians from independence up to 1980s opted for a strategy of flexible and adroit coalition politics within these two major Sinhala nationalist parties (McGilvray, 2001, p. 9). However, in the Eastern Sri Lanka, Muslims had played their political roles with the collaboration of the Tamil parties. Therefore, the Muslim political leaders never thought of having a separate political party until the Sri Lanka Muslim Congress (hereafter, SLMC) was founded on $21^{\text {st }}$ September 1981 in Kattankudy, as a political movement which was later declared as a political party in 1986 and recognized by the election department in 1988 (Jeyaraja, 1998, p. 103). The progenitor of the SLMC was M.H.M. Ashraff who hailed from Sammanthurai, one of the predominantly Muslim villages in the Eastern province, and started his public life as a lawyer in Kalmunai area. Initially, he worked with the Muslim United Liberation Front (MULF), a political movement in Kalmunai area of the Eastern province. He worked through that movement for the benefit of the Muslim community (Cader, 2002, p. 36). At that time, he got the chance to make alliance between the MULF and the Tamil United Liberation Front (hereafter, TULF), the major political party of Tamil community at the 1977 general elections. However, the frustrated experiences, he gained from the TULF, induced him to form the SLMC. 
With the formation of SLMC, Ashraff was able to rise into prominence in the national politics. In 1988, the SLMC with political recognition contested the provincial council election held in to the North-Eastern provincial council in 1988 and won 17 seats and became a strong opposition party in the first Council. At the same time, the SLMC was able to secure 29 seats all over the Island in the provincial council elections held in 1988 and gained popularity in Sri Lanka politics. Further, in 1988, SLMC supported the UNP candidate for presidential election which led to the emergence of its candidate to the Presidency. In 1989 general elections, the SLMC was able to gain four seats in the parliament. In 1994, SLMC joined the People's Alliance (hereafter, PA) coalition at the general elections, got seven (07) seats, and became a 'Queen-maker' in the national political life of Sri Lanka and later joined the PA government as equal partner.

The SLMC fought for the rights and privileges and other necessities of the Muslim community, and advocated for a separate power-sharing unit. It gave voices to those Muslims forcefully ejected from the Northern Province in 1990; the terrorist activities against the Muslims in the Eastern province; and actively participated in the relief activities of displaced Muslims. Furthermore, with the political support from the PA government in 1994, the SLMC was very keen in resettling and rehabilitating the conflict and war affected communities in the North-Eastern provinces. The ministerial positions offered to the SLMC, strengthened the SLMC's efforts in this direction. These ministries focused their attention to education, irrigation, health, infrastructure, livelihoods, socio-cultural sectors and so forth. The establishment of South Eastern University of Sri Lanka in 1995, and the foundation laid for the building of a new harbor at Oluvil were identified as the major milestone of the SLMC on behalf of the Eastern Muslims. However, it should be noted that the SLMC never limited its services and advocacy policies to the Muslims community only. Rather it advocated for and contributed to the improvement of all communities affected in the course of the ethnic conflict and civil war. In this regard, the SLMC leadership later formed National Unity Alliance, a political party on ideas of playing national cohesive politics (For more information on this regard, see: Aliff \& Sarjoon (2010); Cader (2002)). (Further, refer section five more details on SLMC role in Muslim advocacy politics).

However, with the demise of its founding leader, the M.H.M. Ashraff in an aircraft accident on $16^{\text {th }}$ September 2000 , the party had to face minor and major splits and more parties emerged from it based on interests and posed a number of political challenges to the Muslim minority in Sri Lanka. A systemic analysis of the role of Muslims in the peace process revealed that even though the advocacy politics of the SLMC failed to accommodate the interests and rights of the affected Muslims, it however reconciled their grievances. The SLMC made the Muslims issues popular and internationalized, and contributed in transforming the political status of the Muslims community into 'Queen or King-makers.'

\section{Muslims Position on Peace Process: From 1980s to 2006}

Even though the Sri Lankan ethnic conflict has roots from the issue of power sharing to ethnic groupings, and Muslims too demanding for a power-sharing unit, however, as Christine Wagner reveals, discussions on power-sharing as a means to resolve the conflict in Sri Lanka between Sinhala majority and Tamil minority have neglected the role of other minority groups like Muslims for many years (Wagner, 2006, p. 87). Even though there were requests from Muslim community, the issues or the voices of Muslims were not been taken into consideration from the beginning of peace process in Sri Lanka. To cite examples, there were attempts to find political solution with Indian mediation in the middle of 1980s; however, during the peace talks, no Muslim groups were given the opportunity to participate in any of the peace talks. During the first round of talks, the Tamil groups requested the government to submit its proposal for solution. For this purpose, government called for an all-party conference to finalize a proposal (Rupasinge, 1998, p. 73). On that occasion, Muslims were unable to send their groups to represent or to present their proposals. Since the executive President of that time, J.R. Jayewardene did not consider the Muslim's problem as a serious one; he did not allow Muslim delegation at the conference. As a result, nothing about the wellbeing of the Muslims was discussed in the government's proposal to establish District Development Councils. Tamil groups rejected the proposal in totality and submitted four important demands, which had no benefits to the Muslims. These four demands were later referred to as 'Thimpu principles' (Ghose, 2003, p. 109). On this principle, they emphasized the autonomy of their motherland. Tamils motherland, according to their perception was the total geographical area covering the Northern and the Eastern provinces including the Muslim majority areas. Since the failure of the Thimbu talks, the incidents of violence once more started spreading out over the areas in the Northern and the Eastern provinces.

Another example of the negligence of the Muslims' interests in the peace process was the Indo-Lanka Accord and the formation of Provincial Council system in 1987. Since the LTTE returned to violent agitations after Thimbu Talks, the Sri Lankan government imposed restriction of food supply to the Northern Province which caused the Northern province abnormal and civilian displacement to Tamil Nadu, the nearest Indian state. This 
made India once again to intervene in Sri Lanka's ethnic conflict and impose India-favorable resolution package (Missra, 1995). After many rounds of talks, the leaders of both governments signed the historic 'Indo-Lanka Accord' on $29^{\text {th }}$ July, 1987 in Colombo. The main feature of the accord was to make an amendment in the Sri Lankan constitution in order to establish Provincial Councils based on devolution of power. It is however, noted that the Muslims' positions were not given due consideration in the accord, even though they had tabled their grievances. The special feature of the accord was the temporary amalgamation of Eastern province with the Northern Province and the establishment of the North-Eastern provincial council (Missra, 1995, p. 113). The side effect of this provision was the reduction of the strength of Muslim positions from $33 \%$ to $17 \%$ and the domination of Tamils in the provincial administration. It was criticized by the Muslims that in the matters of resource allocation and employment opportunities, the Muslims were not properly considered. This has induced the Muslim community in the North-Eastern province to demand for a separate Provincial Council. In fact, as Fousar (1997, p. 12) mentioned, the proposal of establishing the North-Eastern provincial council has not been effective as expected to solve the ethnic conflict. In addition, it made the trend of alienating the Muslims interests, rights, security and safeguards in the provinces.

However, the electoral coalition between the SLMC and the PA led the formation of central government with the support and partnership of the SLMC in August 1994, the first time in the history of national politics and Muslim politics in Sri Lanka. The partnership politics paved way for the victory of PA candidate, Mrs. Chandrika Kumaratunga in the presidential election, held in November, the same year. The leader of the SLMC, M.H.M Ashraff, as main coalition partner and a powerful cabinet minister became the voice for the rights and privileges of the Muslims in the cabinet and parliament. Furthermore, this position helped him to demand equal share on behalf of the Muslims to redress the conflict related grievances. In her capacity as the Prime Minister and then the President, Chandrika Kumaratunga made full attempts at bringing a peaceful settlement with the Tamil groups, especially with the main rebel group, the LTTE during her regime. Peace talks were convened between the government of Sri Lanka and the LTTE from April 1994 until October 1995. As a result, there was a declaration of ceasefire. But, in April 1995, not only did the LTTE violated the atmosphere of ceasefire, but also refused to continue with the peace negotiations (Dissanayake, 2004, p. 161). However, the government on her part continued to press for solution to the crises through parliamentary politics.

At the all-party peace conferences, the ethnic issues were centered on sharing powers to regions and ethnic groups. The SLMC also proposed a separate Muslim majority regional council covering geographical location of the coastal fringe with the Muslim predominant electorates of Kalmunai, Sammanthurai and Pottuvil in Amparai district to ensure the political autonomy of the Muslim community. Similarly, in the Eastern province, instead of merging the Northern and the Eastern provinces, the SLMC proposed a separate new Eastern province with Trincomalee and Batticoloa districts (Fousar, 1997, pp. 38-41). The role-played by M.H.M Ashraff as a senior lawyer and the SLMC's position as the main coalition party, induced the government and the President to contemplate over the attainment of the solution for the Muslims issues too. After some rounds of peace talk on power-sharing and the new draft constitution with the proposal to establish Regional Councils based on devolved power, was tabled on October 1997. This proposal incorporated the SLMC's proposal of South Eastern Regional Council. A final draft of constitution was placed in parliament on $2^{\text {nd }}$ August 2000 for its approval. On that occasion, the SLMC leader was advocating the proposed constitution for three hours, through his historic speech in the parliament.

However, the sudden demise of the founding leader of SLMC, MHM Ashraff and the change of government created new political environment in Sri Lanka. Even though the SLMC gained more seats in the parliament in the general election held in 2000, however, in the course of time, the party loss its position that was recognized by the PA government when M.H.M. Ashraff was the leader. In addition, the PA government had to dissolve the parliament after one year in 2001 and to call for new general election due to lack of support from the SLMC. At the general election held in December 2001, the United National Front (hereafter, UNF) with the support of the SLMC won the election and formed new government. This situation induced the SLMC to advocate for Muslim's interests. The SLMC declared Hundred (100) days deadline to government to fulfill its proposal of power-sharing and other rights and benefits of the Muslims, including the demand to create a separate administrative district in the coastal belt of Amparai district for the sake of Tamil speaking people. However, the government never attempted to fulfill the SLMC's demand.

It is further emphasized that the changing of government in December 2001 under the leadership of the UNP made a new shift in the negotiation process to ethnic conflict in Sri Lanka. With the formation of new government, the LTTE unilaterally came forward to stop fighting and declared ceasefire on $25^{\text {th }}$ December 2001. Both parties accepted Norway to act as the peace facilitator in the negotiation process. Accordingly, after the 
peace negotiations, a Memorandum of Understanding (hereafter, MoU) was signed on $22^{\text {nd }}$ February 2002 (Sørbø et al., 2011, pp. 35-36; also see: Imtiyas, 2009, pp. 414-16). This MoU had the provisions not only for ceasefire, but also for the reservation of the livelihood of the conflict-affected people. More so, this MoU did not mention anything specifically regarding the Muslims issues in the North-Eastern province, which caused Muslim civil society to advocate for Muslims interests and to question the role of the SLMC in peace process. In this regard, the student community of South Eastern University of Sri Lanka (a university dominated by Muslim students at that time) convened a conference on $13^{\text {th }}$ April 2002 under the caption 'Muslim position in solving ethnic issues' and declared that appeal should be made to the government to sincerely consider on humanitarian ground, the Muslims' issues and their rights and interests and also to include them in the peace talks. Also, the conference declared that the Muslims should also be given equal opportunity in power-sharing mechanism (See: Cader, 2003; Mohamed, 2005, pp. 97-98). The above mentioned MoU paved ways for six rounds of peace talks under the Norwegian facilitation from September, 2002 to March, 2003. However, none of the talks treated Muslims as a separate entity to participate or placed their problems on the agenda. Even though the coalition agreement between the SLMC and the UNF government ensured a separate Muslim entity in the peace talks, and the joint statement, which was signed between the SLMC leader and the LTTE leader on $13^{\text {th }}$ April, 2002 also recognized the Muslims separate participation, none of these promises were fulfilled. But, the Muslim community was severely targeted even at the period of ceasefire monitored by international mission and the Praba-Hakeem agreement was alive. It was reported in June 2002, that violence flared up in Mutur and Valaichchenai, predominant Muslim villages in the Eastern province, leading to the abduction or killing of 13 Muslims and the destruction of more than 150 million rupees worth of their properties (Mohideen, 2006, pp. 313).

In opposing the positions of the Sri Lankan government and the LTTE on Muslims issues at the peace talks, the student community of South Eastern University of Sri Lanka, convened a 'Muslim National Revival Conference' on $29^{\text {th }}$ January 2003, and announced the following political declaration, referred as Oluvil Declaration:

"The North-Eastern Muslim form a separate nation with its distinct identity of religion and culture; the Northern and the Eastern province are the traditional homeland of the Muslims; the Muslims in the Northern and the Eastern provinces have the rights to self-determination to charter for their own destiny; the Muslims must be guaranteed autonomic self-governing political unit merging all the Muslim majority areas of the Northern and the Eastern provinces; and the socio-economic, political and cultural rights of fellow Muslims, living in scattered areas outside the Northern and the Eastern Provinces must be ensured..." (McGilvray \& Raheem, 2007, p. 4; Student Union, 2003; Jeyaraj, 2003, p. 14).

In short, the Oluvil Revival Conference and its Muslim National Declaration brought attraction and moral supports among Muslims and others. However, Muslims were never given separate representation at any of the peace talks conducted during this period or thereafter. Due to the problem that cropped up between the UNF government and the President of the country, who had been elected on the platform of the opposition party, the efforts towards regaining peace in the country collapsed. The issues ended with the dissolution of parliament by the president. Although the United People Freedom Alliance (hereafter, UPFA) gained control of the new parliament in April 2004, and the Presidency in November 2005, it had encountered numerous problems. The newly elected president, Mr. Mahinda Rajapakse of the UPFA, attempted to restart the peace process as assured in the election campaigns. Two rounds of peace talks were conducted under the UPFA regime in 2006, but none of those talks considered Muslims as a separate party to the conflict or peace process. However, both the UNF and the UPFA government strategically handed the Muslims' interests and demands by admitting a Muslim member in the negotiation delegations.

The point to be emphasized with regards to the role Muslims play in ethnic conflict resolution process is that in most of the peace talks, especially of foreign mediated and facilitated peace talks, the Muslims interests and demands were never given fully consideration. Even though the separatist demand and violent civil war seems to end in Sri Lanka, it is the Muslim community has been facing a lot of challenges in the post-war era. For the last few years, the ethnic, religious, and cultural distinctiveness of Muslim community have vehemently been questioned and targeted.

\section{Conclusions}

As a result of the ethnic conflict and civil war, Sri Lanka, once called as the 'Pearl of the Indian Ocean', later described as the 'Island of tears' by scholars and researchers. In the past history, there were records of mutual understandings, cooperation and sympathy among ethnic groups. However, the emergence of ethnic conflict caused the ethnic groups to live with mutual suspicions and antagonism. Even though the civil war has come to 
an end in Sri Lanka, the root causes for the suspicions and antagonism among ethnic groups is not yet removed. The ethnic conflict not only has placed the Sinhalese and Tamils in opposition, but also has affected the Muslim community, especially those of the North-Eastern provinces to a greater extend. However, most of the initiatives attempted to find solution to the ethnic conflict have failed to address the due effects of ethnic conflict on Muslim community and give them due place in peace negotiations. From 1980 till 2006, except for the period 1995-2000, in most of the peace talks Muslims factors were put aside, arguing that the Tamils were the most affected people and that the solution need to be identified to solve the Tamils questions only. Therefore, Muslims were abandoned and left helpless as there were no parties for the Muslims to speak on their behalf. Even though the formation of a Muslim district political party, the SLMC has raised its voice to the Muslim community, however, the leadership vacuum created after the demise of its founder leader made the party vulnerable in national politics. It is the defeat of the LTTE forces and the reunification of the LTTE controlled areas by the Sri Lankan forces in 2009 that contributed to the re-emergence of nationalistic hegemony in Sri Lanka. On this backdrop, the Muslims of Sri Lanka have come to be targets once against, as it happened hundred years ago in 1915. The recent incidents of attracts on religious and cultural identity reveals that there would be a potential treat of religious conflict in Sri Lanka and the Muslims can be victimized in this process. It must be emphasized here though that in the case of conflict resolution, considering the demographic realities in the Eastern province, it is obvious that any settlement to resolve the ethnic conflict are unlikely to be achieved without the consent and participation of the Muslim community, particularly those of the Eastern province.

\section{References}

Ali, A. (2001). Plural identities and political choices of the Muslim community. Colombo: Marga Institute.

Ali, A. (2004). The Muslims of Sri Lanka: An ethnic minority trapped in a political quagmire. Inter-Asian Cultural Studies, 5(3), 372-383. http://dx.doi.org/10.1080/1464937042000288679

Aliff, S. M., \& Sarjoon, A. (2010). The break-up of Sri Lanka Muslim Congress: A critical analysis of the causes and the impacts on the Muslim politics of Sri Lanka. In D. Devanathan, C. Subramanian, \& D. Sivakumar (Eds.), Globalization (pp.12-24). Chennai: Scitech Publications (India) Pvt Ltd.

Azees, I. L. M. A. (1907; 1956). A Criticism of Mr Ramanathan's Ethnology of the 'Moors' of Ceylon. (Reprinted). Colombo: Sri Lanka Muslim Cultural Center.

Balasingham, A. (2004). War and peace: Armed struggle and peace efforts of liberation tigers. England: Fairmax Publishing Ltd.

Britto, C. (1879; 1999). Yalpana vaipava malai (The history of the Kingdom of Jaffna). (Reprinted). New Delhi: Asian Educational Service.

Cader, M. L. A. (2002). Ashraff the political sage. Peradeniya: Sri Lanka Political Research Center.

Cader, M. L. A. (Ed.). (2003). The position of Muslims in the context of solving ethnic problems in Sri Lanka. Oluvil: South Eastern University of Sri Lanka.

De Silva, K. M. (1981). A History of Sri Lanka. New Delhi: Oxford University Press.

De Silva, K. M. (Ed.). (1993). Sri Lanka: Problems of governance. Kandy: ICES.

Department of Census and Statistics. (2013). Census Report-2013. DCS: Colombo.

DeVotta, N. (2004). Blowback: Linguistic nationalism, institutional decay, and ethnic conflict in Sri Lanka. Stanford: Stanford University Press.

Dewaraja, L. (1994). The Muslims of Sri Lanka, 1000 years of ethnic harmony 900-1915 AD. Colombo: Lanka Islamic Foundation.

Dissanayake, T. D. S. A. (2004). War or Peace in Sri Lanka. Mumbai: Popular Prakashan Publication.

Fazil, M. M. (2005). The Muslim factors in the Sri Lankan conflict. In G. Frerks, \& B. Klem (Eds.), Dealing with diversity: Sri Lankan discourse on peace and conflict (pp.161-182). The Hague: Netherlands Institute of International Relations.

Fousar, M. (1997). South-eastern region: A leading land for the unity of three ethnic communities. Colombo: SLMC Publication.

Francis, M.G. (1913). History of Ceylon. New Delhi: Asian Educational Service.

Gamage, S., \& Watson, I. B. (Eds.). (1999). Conflict and community in contemporary Sri Lanka: 'Pearl of the East'or the 'Island of Tears'? New Delhi: Sage Publications. 
Ghosh, P. S. (2003). Ethnicity versus nationalism. Colombo: Vijitha Publications.

Godrongton, H. W. (1970). A short history of Ceylon. New York: Books for Libraries Press.

Gunethilake, G. (2001). The ethnic dimension of socio-economic development. Colombo: Marga Institute.

Hasbullah, S. H. (2001). Muslim refugees: Forgotten people in Sri Lanka's ethnic conflict. Puttalam: Research Action Forum for Social Development.

Imtiyaz, A. R. M. (2009). The Eastern Muslims of Sri Lanka: Special problems and solutions. Journal of Asian and African Studies, 44(4), 407-427. http://dx.doi.org/10.1177/0021909609105092

International Crisis Group. (2007). Sri Lanka's Muslims: Caught in the crossfire. Crisis Group Report. No.134, London.

Ismail, J. (2013, February 25). A tribute to the cordial relations between Muslims and Sinhalese in the past. Colombo Telegraph. Retrieved from https://www.colombotelegraph.com/index.php/a-tribute-to-the-cordial-relations-between-muslims-and-sinh alese-in-the-past/

Jayaraja, A. (1998). Kilakkin ithayam thesattin uthayam (Heart of the east is nation's rise). Colombo: New Lights Publication.

Jeyaraj, D. B. S. (2003, February 9). Oluvil declaration proclaims advent of Muslim nation (thesam). The Sunday Leader.

Jeyawardena, K. (1990). Ethnic and Class conflict in Sri Lanka. Colombo: Sanjiva Press.

McGilvray, D. B. (1998). Arabs, Moors and Muslims: Sri Lankan Muslim ethnicity in regional perspective. Contribution to Indian Sociology, 32(2), 433-483. http://dx.doi.org/10.1177/006996679803200213

McGilvray, D. B., \& Dannis, B. (2001). Tamil and Muslim identity in the Eastern Sri Lanka. Colombo: Marga Institute.

McGilvray, D. B., \& Raheem, M. (2007). Muslim perspectives on the Sri Lankan conflict. Washington: East-West Center.

Missra, S. S. (1995). Ethnic conflict and security crises in Sri Lanka. Delhi: Kalinga Publications.

Mohamed, A. R. (2005). Ilankayin Inappirachinaith Theervum Muslimkalum (Conflict resolution in Sri Lanka and the Muslims). AIRC, Oluvil: South Eastern University of Sri Lanka.

Mohideen, M. I. M. (2002). The need for power-sharing arrangements for the Muslims in the North-East Sri Lanka. Colombo: (author's publication).

Mohideen, M. I. M. (2006). Sri Lanka peace process and the Muslim question. In K. Rupesinghe (Ed.), Negotiation peace in Sri Lanka (Part Two) (pp. 305-329). Colombo: Foundation for Co-Existence.

Ponnambalam, S. (1983). Sri Lanka: The national question and Tamil liberation struggle. London. (n.m).

Rasanayagam, M. C. (1993). Ancient Jaffna (2nd ed.). New Delhi: Asian Educational Service.

Rupasinge, K. (Ed.). (1998). Negotiating peace in Sri Lanka: Efforts, failure and lessons. London: International Alert.

Sebastian, A. (2012). Complete illustrated history of Sri Lanka. Colombo: Vijitha Yapa Publications.

Shukry, M. A. M. (Ed.). (1986). Muslims of Sri Lanka: Avenues to antiquity. Beruwela-Sri Lanka: Jaamiah Naleemiya Institute.

Sørbø, G. J., Goodhand, B., Klem, A. E., Nissen, \& Selbervik, H. (2011). Pawns of peace: Evaluation of Norwegian peace efforts in Sri Lanka, 1997-2009. Oslo: NORAD.

Student Union. (2003). Muslim national revivals and political demands (Oluvil Declaration). Oluvil: South Eastern University of Sri Lanka.

Wagner, C. (2006). Minorities and power-sharing: The role of Muslims. In L. Fernando, \& S. Wijewardena (Eds.), Sri Lanka's ethnic conflict in the global context (pp. 87-102). Colombo: University of Colombo.

Zackariya, F., \& Sanmugarathnam, N. (1997). Communalization of Muslims in Sri Lanka: A historical perspective (pp. 7-46). Alternative Perspective. Colombo: Muslim Women's Research and Action Forum. 


\section{Notes}

Note 1. The ancient history of Sinhalese and Buddhism in Sri Lanka can be found in very popular chronological documents, the Mahavamsa, written in Pali, around the $4^{\text {th }}$ century, and the Chulavamsa, probably panned in the $13^{\text {th }}$ century. These two documents have been considered as the very basic historical documents of Sinhalese and Buddhist history in Sri Lanka. For further reading see also, Sebastian (2012), De Silva (1981). The historical origin of Sri Lankan Tamil can be found in the works of Brito (1999), Rasanayagam (1993) \& Francis (1913).

Note 2. The histories of Muslims in Sri Lanka are recorded mostly by the foreign travelers who visited Sri Lanka. See the works of Dewarajah (1994), Sukkry (Eds.) (1986) and Azees (1907(1957R) for the understanding of the history of Sri Lankan Muslims.

Note 3 . It is to note that the $29.28 \%$ of Sinhalese population in 1963 increased to $38.73 \%$ in 2012 . Likewise, $46.11 \%$ of Muslim population declined to $38.73 \%$ in 2012 . The most affected community on this regard is the Tamils whose $23.23 \%$ declined to $17.40 \%$ in 2012. For more details, see: Census Reports-1963, 1971, 1981, 2012.

Note 4. LTTE (Liberation Tigers of Tamil Eelam) was the major and popular movements among the separatist Tamil militant movements functioned until 2009 in Sri Lanka. It had all kind of forces including air force and the latest military equipment. In the last battlefield of civil war in 2009, most of its forces, including its leader were killed or captured by the Sri Lankan government forces. However, the movement is still running a transnational state.

\section{Copyrights}

Copyright for this article is retained by the author(s), with first publication rights granted to the journal.

This is an open-access article distributed under the terms and conditions of the Creative Commons Attribution license (http://creativecommons.org/licenses/by/3.0/). 